\title{
Arzénkezelés hatása zöldborsó (Pisum sativum L.) arzén- és foszfor- koncentrációjára, valamint szárazanyag-produktumára
}

\author{
${ }^{1}$ VÁRALLYAY Szilvia, ${ }^{2}$ BALLÁNÉ KOVÁCS Andrea, ${ }^{1}$ SOÓS Áron és \\ ${ }^{1}$ KOVÁCS Béla
}

${ }^{1}$ DE-MÉK Élelmiszertudományi Intézet, Debrecen

${ }^{2}$ DE-MÉK Agrokémiai és Talajtani Intézet, Debrecen

\section{Bevezetés}

Az arzén a természetben elöforduló toxikus elem, mely jelen van a levegöben, vízben, talajban, földkéregben valamint az élö szervezetekben (MANDAL \& SUZUKI, 2002). Az arzén regionális jellegü feldúsulása környezetünkben egyrészt természetes, másrészt antropogén eredetű lehet. A természetes eredetü arzénszennyezés elsősorban arzéntartalmú kőzetek mállása során, valamint vulkáni müködés hatására alakulhat ki (CHILVERS \& PETERSON, 1987). A geológiai eseményeken felül főleg ipari tevékenység eredményeként kerülhet az arzén a talajba, illetve a talajvízbe. A különböző bányászati tevékenységek, az arzéntartalmú növényvédö, illetve rovarölö szerek, valamint az arzént tartalmazó fakonzerváló anyagok használata, továbbá a geológiai eredetü arzént tartalmazó talajvizek mezőgazdasági hasznosítása is hozzájárult/hozzájárul az adott helyen megjelenő szennyeződések kialakulásához (WILLIAMS et al., 2005; GoNZAGA et al., 2006).

A mezőgazdasági müvelésbe vont talaj, valamint a felszín alatti vízkészlet arzén szennyezettsége a világ valamennyi részére kiterjedő globális problémát jelent (MANDAL \& SuZUKI, 2002; LiAO et al., 2004). Jelen van többek közt Argentína, Ausztria, Amerikai Egyesült Államok, Chile, Kína, India, Új-Zéland, Tajvan, Thaiföld, valamint Magyarország egyes részein is (Mukherjee \& Bhattacharya, 2001; MANDAL \& SUZUKI, 2002; SMEDLEY \& KinNIBURGH, 2002). E tekintetben hazánk területén elsősorban az Alföld térségében az arzén a felszín alatti vízkészlet egyik legjelentősebb szennyezője (ROWLAND et al., 2011).

Az arzén a talajban (KoCH et al., 2000; MATTUSCH et al., 2000) és a talajvízben (MANDAL \& SUZUKI, 2002) elsődlegesen szervetlen formában fordul elő. Jól levegőzött talajokban oxidatív körülmények között arzenát formájában gyakran erősen kötődik vas- és magnézium oxidhoz, valamint hidroxidhoz, illetve szerves anyagokhoz. Anaerob körülmények között, tömörödött, vízzel borított, levegötlen talajok esetén az arzenit a jellemző szervetlen arzénforma (MANDAL \& SUZUKI, 2002). A különböző arzénformák toxicitásának tekintetében a szervetlenek toxikusabbak, mint a szervesek. A szervetlen arzén vegyületek közül pedig az As(III) toxikusabb, mint az As(V) (UlLRICH-EBERIUs et al., 1989). Ez egyrészt annak köszönhető, hogy az As(III) az ásványi anyagok felszínén kevésbé kötődik

Postai cím: VÁRALlYAY SZILVIA, DE-MÉK-ÉTI, 4032 Debrecen, Böszörményi út 138.

E-mail: varallyay.szilvia@agr.unideb.hu 
meg, azaz mobilisabb, mint az As(V) (CULLEN \& REIMER, 1989). KÁDÁR (1991a, 1995) mezőföldi nehézfém terheléses tartamkísérletében azt tapasztalta, hogy az arzén a talajban nehezen mozog, ezért a csapadékvízzel nem mosódik le.

A talajban a növények számára hozzáférhető arzén mennyiségét számos környezeti tényező $\left(\mathrm{pH}, \mathrm{E}_{\mathrm{h}}\right.$, szervesanyag-tartalom, más ionok jelenléte, egyéb tényezők) határozza meg (MORENO-JIMÉNEZ, 2012).

$\mathrm{Az}$ arzéntartalmú vízzel öntözés, valamint az arzénnal szennyezett talajon a növénytermesztés által az arzén a növények számára elérhető (QUAGHEBEUR \& RENGEL, 2003; RAAB et al., 2007). Az arzén felvételének következtében olyan növényfiziológiai folyamatok sérülhetnek, melyek súlyos rendellenességekhez vezetnek (WELLS \& GILMOR, 1977; SMITH et al., 2010). Növény esetén az arzéntoxicitás tünete lehet: a magvak csirázó képességének, valamint a hajtás és gyökér növekedésének csökkenése, illetve a fotoszintézis gátlása (CASTILLOMichEL et al., 2007). A gyökerek sárgás-barnás elszíneződésén, valamint a leveleken megjelenő vörösesbarna nekrotikus foltokon túl a nagy koncentrációban jelenlévő arzén a növények elhalásához vezet (KABATA-PENDIAS, 2010).

$\mathrm{Az}$ arzén a növények számára nem esszenciális, sőt toxikus mikroelem (QUAGHEBEUR \& RENGEL, 2003; RAAB et al., 2007). Egyes szakirodalmak szerint azonban az arzén kis koncentrációban hasznos lehet a növények számára (Gulz \& Gupta, 2000). Kis koncentrációjú arzénkezelésnél terméshozam növekedés volt megfigyelhetö paradicsom, búza, kukorica és rozs esetében (GULZ \& GUPTA, 2000; JACOBS et al., 1970; WOOLSON et al., 1971; XU \& THORNTON, 1985; CARBONELLBARRACHINA et al., 1998a).

A szakirodalmi adatok alapján - az előzőekben említetteken túl - az arzén hatással van a növények ásványianyag-asszimilációjára is. MALLICK és munkatársai (2011) az arzénkezelésnek a kukorica ásványianyag-felvételére gyakorolt hatását vizsgálták. Kísérletük során megfigyelték, hogy a növekvő koncentrációjú kezelések hatására csökkent a Fe és Mn akkumulációja, ugyanakkor a tesztnövény $\mathrm{Cu}$ és $\mathrm{Zn}$ koncentrációjában nem történt változás. CARBONELL-BARRACHINA és munkatársai (1998b) paradicsommal végzett kísérletükben azt tapasztalták, hogy az arzénkezelés hatására a növény $\mathrm{K}, \mathrm{Ca}, \mathrm{Mg}, \mathrm{B}, \mathrm{Cu}, \mathrm{Mn}$ és $\mathrm{Zn}$ felvétele csökkent. Öszi búza tesztnövényen az arzénkezelés eredményeként a $\mathrm{Cu}$ - és a $\mathrm{Zn}$ - mellett a Fe-tartalomban is csökkenő tendenciájú felvétel volt megfigyelhetö (LIU et al., 2008). Ezzel szemben Melo és munkatársai (2009) tesztnövényként ricinust alkalmazva megállapították, hogy az arzénkezelés hatására $\mathrm{Cu}$ és $\mathrm{Zn}$ mellett nőtt a $\mathrm{P}, \mathrm{N}$, valamint a Ca koncentrációja a gyökérben, valamint a P-, Mn- és Zn-tartalom a hajtásban, csökkent ugyanakkor a Mn-koncentráció a gyökérben, valamint a $\mathrm{Cu}$ és Fe-tartalom a hajtásban.

Az arzén növények ásványianyag-asszimilációjára gyakorolt hatását tekintve a $\mathrm{P}$ az egyik leginkább tanulmányozott elem. Ennek oka, hogy az arzenátok és a foszfátok, kémiai felépítésükben hasonlítanak egymáshoz. Ami miatt azonban a növényi felvétel során antagonistaként szerepelnek (KÁDÁR, 1991b; MOKGALAKAMATLALA et al., 2008; PIGNA et al., 2010). Az arzén a foszfor helyére bármely összetett molekulába vagy enzimbe beépülhet, amely így nem képes ellátni eredeti 
feladatát (LiU et al., 1998; CHRISPEELS et al., 1999). A foszfor az ATP és ADP (energia transzfer) molekulák építőköve, továbbá fontos szerepet játszik a fehérje anyagcserében, nélkülözhetetlen a generatív szervek kialakulásában és a termésképzésben. A foszforhiány a szénhidrát- és nitrogén-anyagcsere károsodásához és a növény növekedésének visszamaradásához vezet (PETHŐ, 1993). Amíg a kutatók egy része az As és $P$ közt antagonista kapcsolatot állapított meg (PAIVÖKE \& SIMOLA, 2001; KuMAR et al., 2015), addig más része arról számolt be, hogy az arzénkezelés hatására nő egyes növényi szerv P-tartalma (TU \& MA, 2005; MELO et al., 2009).

$\mathrm{Az}$ arzénnak a növények foszforfelvételére gyakorolt hatását az eddigi tanulmányok főként oldatkultúrás körülmények között vizsgálták. Az ilyen jellegủ kísérletek azonban nem állíthatók párba a szántóföldi növénytermesztéssel. Annak érdekében, hogy a szántóföldi növénytermesztés során az egyes elemek akkumulációjában, valamint az egyéb növényfiziológiai paraméterekben ténylegesen bekövetkező, arzén indukálta változásokat nyomon követhessük, az erre vonatkozó kísérleteket szabadföldi, illetve azzal analóg körülmények között szükséges kivitelezni.

Az előzőekben leírtakból adódóan kutatómunkánk célja, a növekvő koncentrációban arzénnal kezelt talajon termesztett zöldborsó szárazanyagproduktumában bekövetkező változások nyomon követése mellett, a különbözö növényi szervek arzén akkumulációjának megállapítása volt. Vizsgáltuk továbbá a talaj arzén-terhelésének hatását a növényi szervek P-tartalmára. Munkánk az arzénnal kezelt talaj „összes” és „oldható” arzéntartalmának megállapítására is irányult.

\section{Anyag és módszer}

A Debreceni Egyetem Mezőgazdaság-, Élelmiszertudományi és Környezetgazdálkodási Kar Agrokémiai és Talajtani Intézet tenyészházában 2016. április - június között tenyészedényes kísérletet állítottunk be az arzén növények szárazanyag-produktumára és ásványianyag-asszimilációjára gyakorolt hatásának vizsgálatához. Vizsgálataink tárgyát képezte továbbá a kísérlet során alkalmazott talaj „összes” és „oldható” arzéntartalmának meghatározása is, a kísérlet során alkalmazott kezelések függvényében.

\section{A tenyészedényes kísérletben alkalmazott tesztnövény}

A tenyészedényes kísérlet során tesztnövényként a zöldborsót (Pisum sativum L.) választottuk. Döntésünket az indokolta, hogy a hazai zöldségtermesztő terület több mint 70\%-a az arzénnal szennyezett talajvízzel, illetve talajjal érintett Alföld térségében található. Választásunkat erősítette, hogy hazánkban a zöldségfajok közül a zöldborsót termesztik a legnagyobb területen. A kísérletünkben használt Avola a zöldborsók közül az egyik legkedveltebb fajta, mely a konzerv- és hütöipari felhasználásra való alkalmasságának köszönhető. Az Avola borsó korai érésủ velö 
típusú fajta, mely a rövid tenyészidőből adódóan könnyen beilleszthető volt a tenyészházi körülmények között végzett kísérletbe.

\section{A tenyészedényes kísérletben alkalmazott talaj}

A kísérletet a Debreceni Egyetem Mezőgazdaság-, Élelmiszertudományi és Környezetgazdálkodási Kar Látóképi Kísérleti Telepéről származó mészlepedékes csernozjom talajon állítottuk be. A Látóképi Kísérleti Telep a Hajdúsági Löszháton terül el, mely a borsó jelzőnövénnyel végzett tenyészedényes kísérlet szempontjából kiemelkedő jelentőségü, hiszen a borsó számára legmegfelelőbb talajtípus a löszön kialakult meszes vagy mészlepedékes csernozjom talaj. A kísérlet során alkalmazott talaj jellemzöit az 1. táblázat tartalmazza. A közölt talajvizsgálati eredmények az NPK mütrágyázás előtti állapotot mutatják be.

\section{1. táblázat}

A kísérlet során alkalmazott mészlepedékes csernozjom talaj jellemzői

\begin{tabular}{|l|l|}
\hline Mélység (1) & $0-0,3 \mathrm{~m}$ \\
\hline $\mathrm{pH}(\mathrm{KCl})$ & 5,71 \\
\hline $\mathrm{pH}\left(\mathrm{H}_{2} \mathrm{O}\right)$ & 6,58 \\
\hline Arany-féle kötöttség $\left(\mathrm{K}_{\mathrm{a}}\right)(2)$ & 43 \\
\hline $\mathrm{CaCO}_{3}$ & $0,20 \%$ \\
\hline Humusz (4) & $3,54 \%$ \\
\hline AL-oldható $\mathrm{P}_{2} \mathrm{O}_{5}(5)$ & $199 \mathrm{mg} \mathrm{kg}^{-1}$ \\
\hline AL-oldható $\mathrm{K}_{2} \mathrm{O}(6)$ & $451 \mathrm{mg} \mathrm{kg}^{-1}$ \\
\hline KCl-oldható $\mathrm{NO}_{3}$-N+NO $\mathrm{NO}_{2}-\mathrm{N}(7)$ & 8,04 \\
\hline AL-oldható $\left.\mathrm{Na}^{-1}\right)$ & $332 \mathrm{mg} \mathrm{kg}^{-1}$ \\
\hline KCl-oldható $\left.\mathrm{Mg}^{-1}\right)$ & $176 \mathrm{mg} \mathrm{kg}^{-1}$ \\
\hline KCl-oldható $\mathrm{SO}_{4}{ }^{2-}-\mathrm{S}(10)$ & $6,04 \mathrm{mg} \mathrm{kg}^{-1}$ \\
\hline KCl-EDTA-oldható Cu (11) & $5,79 \mathrm{mg} \mathrm{kg}^{-1}$ \\
\hline KCl-EDTA-oldható $\mathrm{Zn}(12)$ & $7,9 \mathrm{mg} \mathrm{kg}^{-1}$ \\
\hline KCl-EDTA-oldható $\mathrm{Mn}(13)$ & $262 \mathrm{mg} \mathrm{kg}^{-1}$ \\
\hline
\end{tabular}

A kísérletben alkalmazott talaj nitrogénnel és foszforral jól, káliummal igen jól ellátott. A kísérleti talajok N-, P- és K-tápanyag-ellátottsági kategóriába sorolásakor a hazai mütrágyázási gyakorlatban alkalmazott MÉM NAK irányelveket vettük alapul (ANTAL et al., 1979). A kísérleti talaj tápanyag-ellátottságát, a zöldborsó fajlagos tápanyagigényét, valamint a tervezett termésátlagot figyelembe véve számoltuk ki az NPK mütrágyák adagjait. A mütrágyázás során a nitrogént $\mathrm{NH}_{4} \mathrm{NO}_{3}(0,568 \mathrm{~g} / 11 \mathrm{~kg}$ talaj $)$, a foszfort $\mathrm{KH}_{2} \mathrm{PO}_{4}(0,229 \mathrm{~g} / 11 \mathrm{~kg}$ talaj $)$, a káliumot pedig $\mathrm{KH}_{2} \mathrm{PO}_{4}\left(0,079 \mathrm{~g} / 11 \mathrm{~kg}\right.$ talaj), illetve $\mathrm{K}_{2} \mathrm{SO}_{4}(0,148 \mathrm{~g} / 11 \mathrm{~kg}$ talaj $)$ formájában juttattuk a talajba edényenként $100 \mathrm{~cm}^{3}$ desztillált vizes oldat formájában. 
Alkalmazott kezelések

Kísérletünk során az arzént arzenát formájában juttattuk ki, mert a jól szellőzött aerob talajok esetén - mint, amilyen a kísérlet során használt mészlepedékes csernozjom talaj is - jellemzően ebben a formában fordul elő. Az arzént káliumdihidrogén-arzenát $\left(\mathrm{KH}_{2} \mathrm{AsO}_{4}\right)$ formájában ioncserélt vízben feloldva juttattuk a talajra, mely során a szükséges koncentrációt arzénra nézve, illetve a talajra vonatkoztatva számoltuk ki. A kísérletben 3, 10, 30, 90, $270 \mathrm{mg} \mathrm{kg}^{-1}$, továbbá kontroll kezelést alkalmaztunk. A növekvő koncentrációjú arzénkezelések a "szennyezetlen", illetve az arzénnal egyre nagyobb mértékben szennyezett, a növények számára már toxikusnak tartott dózist hivatottak prezentálni. Minden kezelésnél három ismétlést alkalmaztunk.

\section{Tenyészedényes kísérlet kivitelezése}

A kísérlet során a tenyészedényekbe 11-11 kg légszáraz, $1 x 1 \mathrm{~cm}$ lyukátméröjü szitán átszitált talajt mértünk be. A mütrágyákat, valamint az arzént $\left(\mathrm{KH}_{2} \mathrm{AsO}_{4}\right)$ alapos keverés mellett oldat formájában (100-100 $\mathrm{cm}^{3}$ edény $\left.{ }^{-1}\right)$ adagoltuk, kiemelt figyelmet fordítva a homogenizálásra.

A növekvő koncentrációjú arzénoldatok, valamint a mütrágyák talajba bekeverését (2016.04.05.) követően 1 hét múlva vetettük el a tesztnövényként alkalmazott zöldborsót. A vetésre 2016.04.12.-én került sor, mely során edényenként $25-25 \mathrm{db}$ borsószem került elvetésre az alábbiakban ismertetett módon. A talaj $200 \mathrm{~cm}^{3}$ desztillált vízzel való beöntözését, illetve a talajfelszín fellazítását követően az egyes borsószemek vetése megközelítőleg 3-4 cm mélységre történt. A vetést a tápközeg felszínének tömörítése követte. Az egyes edényeket kocsikon helyeztük el, véletlen-blokk elrendezésben, így lehetőségünk volt a kocsikat éjszaka, illetve eső esetén tető alá tolni. A vetőmag kelését követően a növények számát edényenként 16 db-ra ritkítottuk. A kísérlet kezdetén megállapítottuk a talaj maximális szántóföldi vízkapacitását, mely az a vízmennyiség, amit az átnedvesített talaj a gravitáció és a szárazabb talajrétegek szívóhatásával szemben képes visszatartani. A talaj nedvességtartalmát a maximális szántóföldi vízkapacitás 60\%-ára állítottuk be. Az evaporáció (vízpárolgás), valamint transzspiráció (növény szabályozott vízleadása) következtében fellépő vízveszteséget naponta pótoltuk, tömeg-kiegészítés alapján. A kísérletben 6 kezelést állítottuk be 3 ismétlésben, mely összesen $18 \mathrm{db}$ tenyészedényt eredményezett.

A tenyészedényes kísérlet feldolgozására a borsó fejlődésének négy különbözö fenofázisában (4 nóduszos állapot, virágzás kezdete, zöldérés, teljes érés) szakaszosan került sor. Az egyes fenofázisokban tenyészedényenként 4-4 db növényt dolgoztunk fel oly módon, hogy a növények talajból történő eltávolítását óvatosan, a gyökerek épségére vigyázva végeztük. A gyökérről a talaj részecskéket folyó csapvíz alatt mostuk le, majd desztillált vízzel öblítettük. A növényeket olló segítségével gyökér, szár, levél, hüvely, illetve borsószem részre szétválasztva, Memmert UF 75 típusú szárítószekrényben $65^{\circ} \mathrm{C}$-on tömegállandóságig szárítottuk. 
Analitikai mérleg (Ohaus) segítségével meghatároztuk az egyes növényi szervek száraz tömegét. A növényi mintákat ezt követően daráltuk, homogenizáltuk.

\section{Talajvizsgálatok}

A minta-elökészítést és az analitikai vizsgálatokat a Debreceni Egyetem Mezőgazdaság-, Élelmiszertudományi és Környezetgazdálkodási Kar Élelmiszertudományi Intézetében végeztük el.

A talajminta vételezésére a vetéssel megegyező napon került sor. Egy-egy edényből 3-3 pontmintát vettünk.

A talajminták „oldható” arzéntartalmának megállapítását, az egyes edényekből vett pontminták alapos homogenizálását, valamint szárítását követően a LAKANENERVIÖ (1971) által kidolgozott módszerrel végeztük.

A talajminták ,összes” arzéntartalmát KovÁCS és munkatársai (2000) által kidolgozott roncsolásos módszer segítségével határoztuk meg.

\section{Növényi minták vizsgálata}

A tömegállandóságig szárított növényi mintákat dörzsmozsár segítségével homogenizáltuk, majd a KovÁCS és munkatársai (1996) által kidolgozott $\mathrm{HNO}_{3^{-}}$ $\mathrm{H}_{2} \mathrm{O}_{2}$-os nedves roncsolásos minta-előkésztési módszert alkalmaztuk. Jelen tanulmány a 4. fenofázisból (teljes érés) származó növényi minták vizsgálata során kapott eredmények bemutatására terjed ki.

\section{Elemanalitikai vizsgálatok}

Az elemanalitikai vizsgálatokhoz iCAP 6300 Dual View (ThermoFisher Scientific) típusú induktív csatolású plazma optikai emissziós spektrométert (ICPOES), valamint Thermo Scientific X-Series 2 Quadrupole típusú induktív csatolású plazma-tömegspektrométert (ICP-MS) alkalmaztunk.

A készülékek mérési és beállítási paraméterei megegyeznek a CZIPA és munkatársai (2015) által alkalmazott paraméterekkel.

\section{Statisztikai módszer}

Az eredmények statisztikai kiértékelésére SPSS 22.0 statisztikai programot alkalmaztunk. A paraméterek és az egyes tényezők közötti összefüggés statisztikai vizsgálatához egytényezős varianciaanalízist és Tukey-tesztet használtunk. 5\%-os p-érték alatt tekintettük az eltéréseket szignifikánsnak. 


\section{Eredmények}

\section{A kísérlet során alkalmazott talaj „összes” és „oldható” arzéntartalma}

A kísérlet során alkalmazott mészlepedékes csernozjom talaj arzéntartalmát laboratóriumi körülmények között állítottuk be. Annak érdekében, hogy ellenőrizzük, hogy a talaj bekeverése során megfelelö homogenitást értünk-e el, vizsgáltuk a talaj „összes” arzéntartalmát. Mivel a növények számára hozzáférhető arzén mennyiségét elsősorban nem az „összes”, hanem az „oldható” arzéntartalom képezi, így vizsgálatunk tárgyát képezte e paraméter meghatározása is. A vizsgálataink során kapott eredményeket a 2. táblázatban foglaljuk össze.

\section{2. táblázat}

A kísérlet során alkalmazott mészlepedékes csernozjom talaj „összes” és „oldható” Astartalma $\left(\mathrm{mg} \mathrm{kg}^{-1}\right)$, valamint ezek aránya az alkalmazott kezelések $(0,3,10,30,90,270 \mathrm{mg}$ $\mathrm{kg}^{-1}$ As) függvényében $(\mathrm{n}=3)$

\begin{tabular}{|c|c|c|c|}
\hline $\begin{array}{c}\text { As-kezelés } \\
\left(\mathrm{mg} \mathrm{kg}^{-1}\right) \\
(1)\end{array}$ & $\begin{array}{l}\text { "Összes" } \\
\text { As-tartalom } \\
\left(\mathrm{mg} \mathrm{kg}^{-1}\right) \\
\text { (A)(2) }\end{array}$ & $\begin{array}{l}\text { "Oldható" } \\
\text { As-tartalom } \\
\left(\mathrm{mg} \mathrm{kg}^{-1}\right) \\
\text { (B)(3) }\end{array}$ & $\mathbf{B} / \mathbf{A}$ \\
\hline $\mathbf{0}$ & $2,07 \pm 0,04^{\mathrm{a}}$ & $0,799 \pm 0,064^{\mathrm{a}}$ & 0,386 \\
\hline 3 & $5,26 \pm 0,25^{\mathrm{ab}}$ & $2,53 \pm 0,37^{\mathrm{a}}$ & 0,481 \\
\hline 10 & $11,6 \pm 0,1^{b}$ & $4,42 \pm 0,18^{\mathrm{a}}$ & 0,382 \\
\hline 30 & $32,1 \pm 0,5^{\mathrm{c}}$ & $15,7 \pm 1,1^{\mathrm{a}}$ & 0,488 \\
\hline 90 & $92,0 \pm 4,3^{\mathrm{d}}$ & $39,1 \pm 2,6^{b}$ & 0,425 \\
\hline 270 & $269 \pm 4^{\mathrm{e}}$ & $153 \pm 17^{\mathrm{c}}$ & 0,569 \\
\hline
\end{tabular}

A fenti táblázatban ismertetett eredmények alapján megállapíthatjuk, hogy a kezeletlen (kontroll) talaj is tartalmazott arzént $\left(2,07 \pm 0,04 \mathrm{mg} \mathrm{kg}{ }^{-1}\right)$, ezáltal a kezelések során a talaj ezen kezdeti arzéntartalmát növeltük meg, amelyből adódóan a talaj összes arzéntartalma adott kezelés esetén és ugyanazon kezelés során alkalmazott arzénkoncentráció nem azonos. Ennek ellenére eredményeink azt bizonyítják, hogy a különböző kezelések esetén az arzén eloszlása a talajban egyenletes volt, így a talaj ebböl a szempontból homogénnek tekinthető.

A talaj „összes” arzéntartalmának csak 38,2-56,9\%-a volt a növények számára felvehető formában jelen, melyhez nagyban hozzájárult, hogy a kísérlet során alkalmazott talaj jelentős humusztartalommal bírt, mely képes a talajhoz kevert arzén egy részét megkötni, elösegítve ezáltal az arzén talaj-növény rendszerben való mobilitásának gátlását. A talajban jelenlévő vas-, magnézium-, alumínium-, valamint mangán-oxidok és hidroxidok felületén az arzén képes megkötődni, mely szintén elősegítette az arzén talajban lévő immobilitását. Mivel a kísérlet során alkalmazott csernozjom talaj pH-értéke semleges körüli $(6,58)$, megközelítőleg neutrális körülmények között a fémek nehezen mennek oldatba, vegyületeik 
stabilnak nevezhetőek, mely hozzájárult ahhoz, hogy a talaj „oldható” arzénkoncentrációja kisebb volt, mint az „összes” arzéntartalma. Mivel kisérletünk kezdetén nagy mennyiségü toxikus elemet juttattunk a talajba, olyan csapadékképzési és adszorpciós folyamatok előtérbe kerülését indukáltuk, melynek következménye, hogy a talaj növények számára hozzáférhető arzén mennyisége jelentősen kisebb, mint a talaj „összes” arzéntartalma.

A kapott eredményeket megvizsgálva arra a megállapításra jutottunk, hogy a kísérlet során alkalmazott arzénkezelések hatására a talaj „összes” arzéntartalma növekvő tendenciát mutatott, a talaj „oldható” arzéntartalma szintén egyenletesen nött. A $270 \mathrm{mg} \mathrm{kg}^{-1}$-os kezelés esetén a talaj „összes” arzéntartalmának már több mint fele $(56,9 \%$-a) volt a növények számára felvehetö formában jelen. A két legnagyobb arzénkezelés (90 és $270 \mathrm{mg} \mathrm{kg}^{-1}$ ) esetén az arzén talajban való megkötődése során abszorbensként szolgáló talajkomponensek telítődnek, így a kezelés során a talajhoz adott arzén nagyobb mértékben már nem képes megkötődni, így ezen meg nem kötődött mennyiség a növények számára hozzáférhető arzén koncentrációját növeli.

SZEGEDI és munkatársai (2013) munkájuk során szintén arra a megállapításra jutottak, hogy a talaj „összes” arzéntartalmának csak kis része hozzáférhető a növények számára.

\section{Arzénkezelés hatása a zöldborsó szárazanyag-produktumára}

Kísérletünk tárgyát képezte a zöldborsó szárazanyag-produktumában bekövetkező változások nyomon követése is, a növekvő koncentrációjú arzénkezeléseknél.

A generatív növényi szervek száraztömegében bekövetkező változásokat az arzénkezelések függvényében az 1-2. ábra szemlélteti.

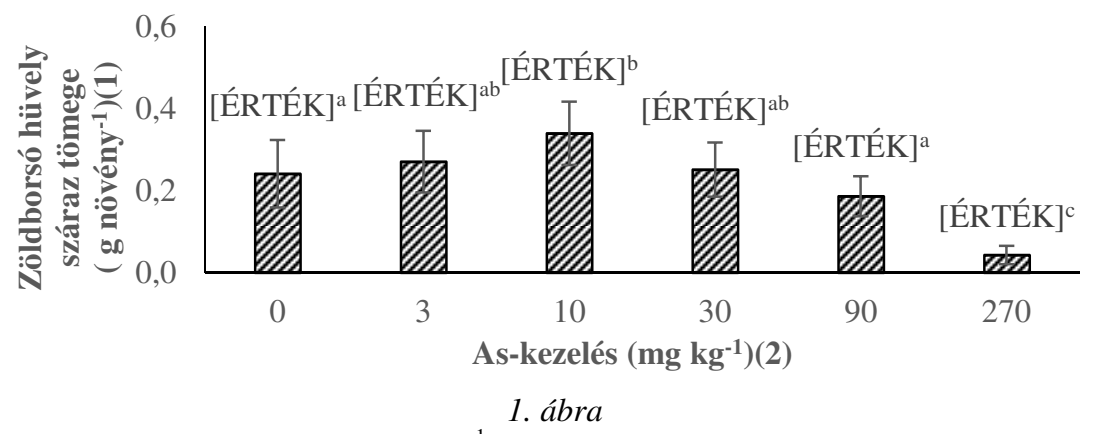

As-kezelés $\left(0,3,10,30,90,270 \mathrm{mg} \mathrm{kg}^{-1}\right)$ hatása a zöldborsó hüvely szárazanyag-tartalmára (g növény $\left.{ }^{-1}\right)(\mathrm{n}=12)$ 


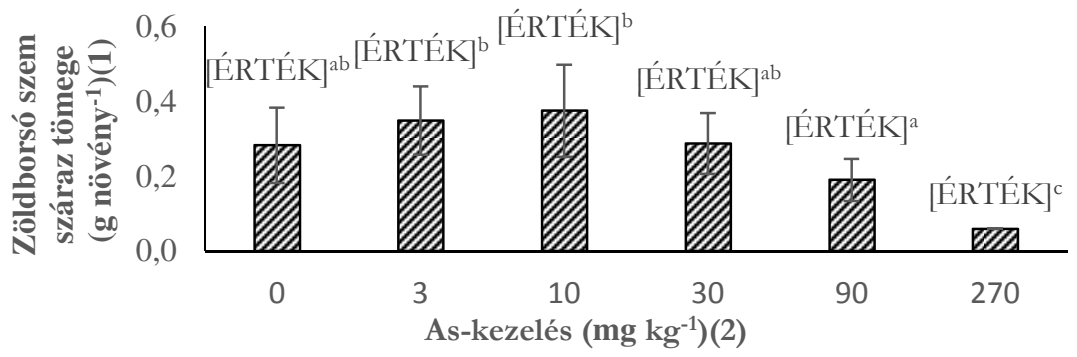

2. ábra

As-kezelés $\left(0,3,10,30,90,270 \mathrm{mg} \mathrm{kg}^{-1}\right)$ hatása a zöldborsó szem szárazanyag-tartalmára $\left(\mathrm{g}\right.$ növény $\left.{ }^{-1}\right)(\mathrm{n}=12)$

A generatív növényi szervek száraztömegét illetően növekvő tendencia volt megfigyelhetö a 3 és $10 \mathrm{mg} \mathrm{kg}^{-1}$-os arzénkezelésnél, a $30 \mathrm{mg} \mathrm{kg}^{-1}$-os kezelés esetén azonban a hüvely és borsószem szárazanyag-tartalma megközelítőleg a kontroll növénynél tapasztaltakkal volt azonos. Ehhez képest a $90 \mathrm{mg} \mathrm{kg}^{-1}$-os kezelés hüvely esetén 22,8\%-os, borsószemnél pedig 35,5\%-os csökkentést okozott. A $270 \mathrm{mg} \mathrm{kg}$ ${ }^{1}$-os kezelés hatására a $10 \mathrm{mg} \mathrm{kg}^{-1}$-os kezelés esetén tapasztalthoz képest közel egy nagyságrenddel kisebb szárazanyag-tartalom volt megfigyelhetö, a szárazanyagfelhalmozás szignifikánsan lecsökkent. A kontroll növény hüvelyének szárazanyagtartalma 5,54-szer, a szemé pedig 4,75-ször volt nagyobb, mint a legnagyobb kezelés esetén. A kapott eredmények alapján a szem szárazanyag-tartalma a $10 \mathrm{mg}$ $\mathrm{kg}^{-1}$-ot meg nem haladó kezelés esetén nőtt, mellyel összhangban számos kutató arról számolt be, hogy az arzén kis koncentrációban való jelenléte terméshozam növelő hatással bír (JACOBS et al., 1970; XU \& THORNTON, 1985; GULZ \& GUPTA, 2000).

Az arzénkezelések koncentrációjának növekedésével csökkent a tesztnövényként alkalmazott zöldborsó gyökerének száraztömege (3. ábra).

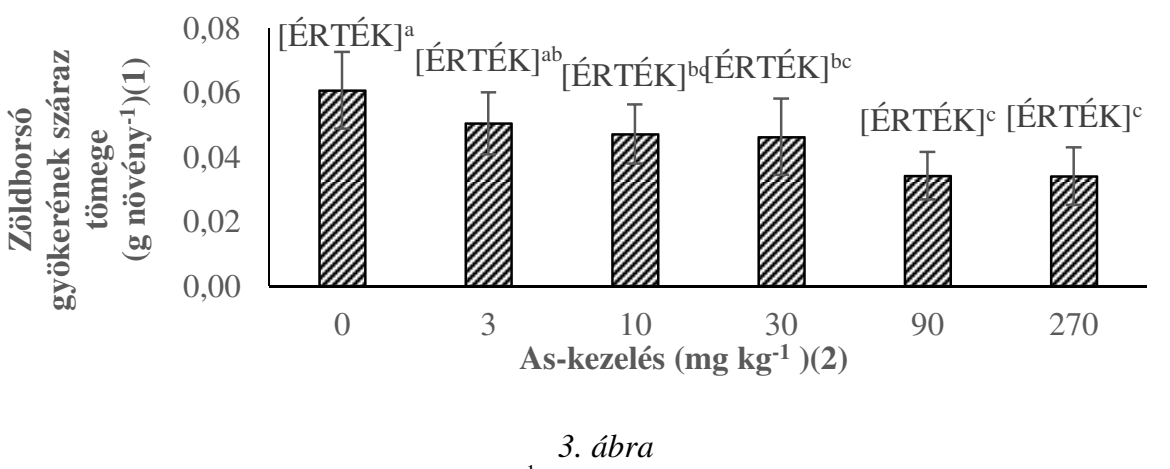

As-kezelés $\left(0,3,10,30,90,270 \mathrm{mg} \mathrm{kg}^{-1}\right)$ hatása a zöldborsó gyökér szárazanyag-tartalmára $\left(\mathrm{g}\right.$ növény $\left.{ }^{-1}\right)(\mathrm{n}=12)$ 
A gyökér szárazanyag-tartalmában bekövetkező jelentős mértékủ csökkenés összefüggésbe hozható a gyökérben nagy mennyiségben felhalmozódó arzén által kiváltott hatásokkal, melyet a későbbiekben részletesen ismertetünk. Az arzénkezelés száraztömegre gyakorolt negatív hatását figyelték meg többek közt AHMED és munkatársai (2006), SHAIBUR és munkatársai (2008), valamint SRIVASTAVA és munkatársai (2009) is.

A további vegetatív szervek (levél, szár) száraztömegében bekövetkező változásokat a 4. ábra szemlélteti.
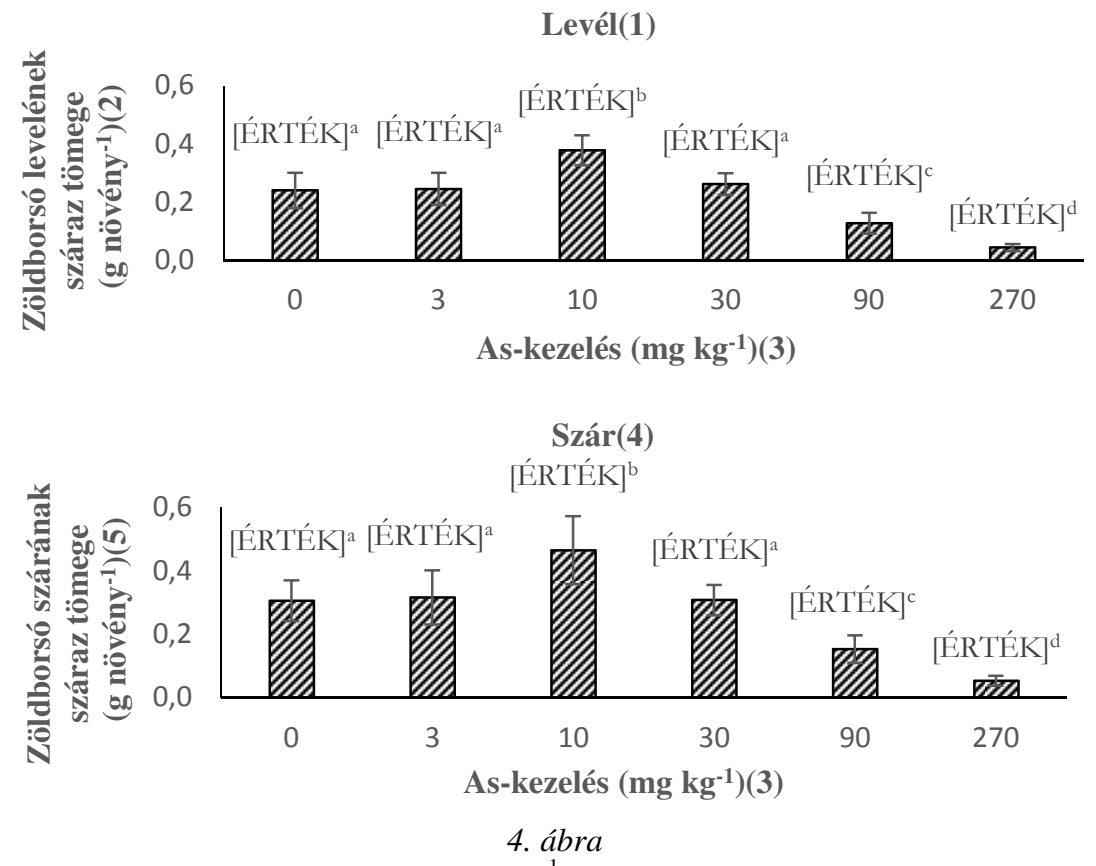

As-kezelés $\left(0,3,10,30,90,270 \mathrm{mg} \mathrm{kg}^{-1}\right)$ hatása a zöldborsó levél, valamint szár szárazanyag-tartalmára $\left(\mathrm{g}\right.$ növény $\left.{ }^{-1}\right)(\mathrm{n}=12)$

A vegetatív növényi szervek közül a szár, illetve a levél esetén a $3 \mathrm{mg} \mathrm{kg}^{-1}$-os arzénkezelés nem okozott jelentős változást a száraztömeg tekintetében. Pozitív hatással az említett növényi szervek szárazanyag felhalmozására egyedül a $10 \mathrm{mg}$ $\mathrm{kg}^{-1}$-os kezelés volt, mely a kontrollhoz képest a szár esetén $52,5 \%$-os, a levélnél pedig $57,9 \%$-os növekedést okozott. Ezt követően a $30 \mathrm{mg} \mathrm{kg}^{-1}$-os kezelés hatására a levél és szár száraztömege lecsökkent a kontroll szintjére. A $90 \mathrm{mg} \mathrm{kg}^{-1}$-os arzénkezelés az elözőekben említettekhez képest szignifikáns csökkenést okozott mind a levél, mind a szár esetén, majd a $270 \mathrm{mg} \mathrm{kg}^{-1} \mathrm{os}$ kezelés hatására további 67,7\%-os (levél) és 65,7\%-os (szár) csökkenés volt megfigyelhető. A kísérletünk során kapott eredmények megerősítik a KUMAR és munkatársai (2015) által tapasztaltakat, akik munkájuk során arra a következtetésre jutottak, hogy az arzén kis koncentrációban $\left(0,01 \mathrm{mM}=0,75 \mathrm{mg} \mathrm{kg}^{-1}\right)$ növelte a kísérleti növény 
száraztömegét, az ezt meghaladó kezelések esetén a száraztömeg a kontrollnál

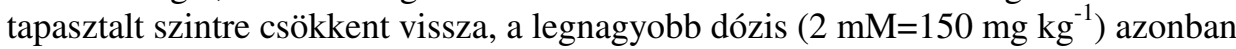
már szignifikáns csökkenést okozott.

Arzénkezelés hatása a zöldborsó egyes szerveinek (gyökér, szár, levél, hüvely, szem) arzén-akkumulációjára

Kísérletünk során elemanalitikai vizsgálatokat végeztünk annak érdekében, hogy megállapítsuk, a növekvő koncentrációjú arzénkezelésnek kitett talaj milyen hatással van a zöldborsó egyes szerveinek arzén-akkumulációjára. Munkánk során külön vizsgáltuk a gyökér, szár, levél, hüvely, valamint borsószem arzéntartalmát (5. ábra).
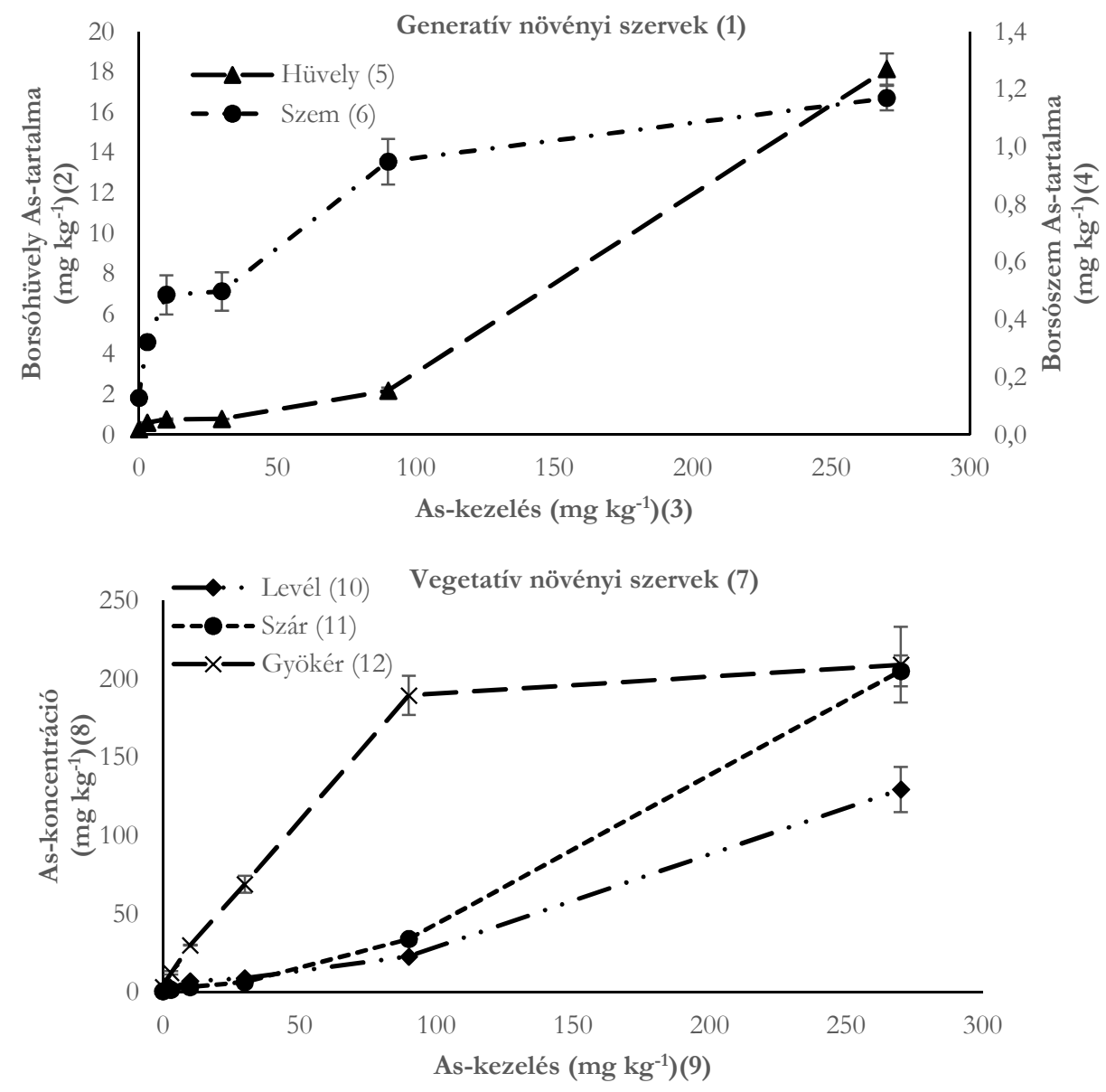

5. ábra

As-kezelés $\left(0,3,10,30,90,270 \mathrm{mg} \mathrm{kg}^{-1}\right)$ hatása a zöldborsó generatív és vegetatív növényi szerveinek As-tartalmára $\left(\mathrm{mg} \mathrm{kg}^{-1}\right)(\mathrm{n}=12)$ 
A fenti ábrák alapján megállapítható, hogy a talaj arzén-koncentrációjának növekedésével valamennyi növényi szerv arzéntartalma nőtt. Statisztikai értelemben a szár, levél, illetve a hüvely esetén a 90 és $270 \mathrm{mg} \mathrm{kg}^{-1}$-os kezelés, gyökér esetén az említett kezelések mellett a $30 \mathrm{mg} \mathrm{kg}^{-1}$-os dózis is szignifikáns növekedést eredményezett az említett növényi részek As-tartalmában. A borsószem arzéntartalmában valamennyi kezelés hatására szignifikáns növekedés következett be.

Az elemanalitikai vizsgálatok alapján a talajból felvett arzén mennyiségének nagy része a gyökérben akkumulálódott és csak kisebb mennyiségben transzlokálódott az egyéb növényi szervek felé. Az arzén felhalmozódása a gyökérben a toxikus hatás egyik lényeges kiváltó oka lehet, hiszen ez által sérülhetnek azok a gyökérben lejátszódó folyamatok, melyek a növény egészének fiziológiáját alapvetően meghatározzák. Az arzénkezelés indukálta stressz folyamatok esetén a növény detoxifikációs mechanizmusának részeként értelmezzük azt, hogy az arzén döntően a gyökérben akkumulálódott. A fitokelatinok - melyek a toxikus fémionok kizárásában, elkülönítésében, valamint megkötésében részt vevő polipeptidek - szintézise elsőként a gyökérben kezdődik meg, hiszen ez az a növényi rész ahol az arzén a növényi felvétel során elöször megjelenik, illetve ahol a kísérleti eredmények alapján döntően akkumulálódik (SCHMÖGER et al., 2000). A fitokelatinok termelése energiaigényes folyamat, az ilyen jelegü fémkötỏ polipeptidek szintézisének energia felhasználása a gyökér növekedésének rovására történik. A növekvő koncentrációjú arzénkezelések hatására a kísérletünk során tesztnövényként alkalmazott zöldborsó gyökerének száraztömegében bekövetkező jelentős mértékủ csökkenés összefüggésbe hozható a fitokelatinok által kiváltott gyökérnövekedés gátló hatásával. A vizsgálataink során kapott eredmények alapján megállapítható továbbá, hogy a $90 \mathrm{mg} \mathrm{kg}^{-1}$-os Askezelésnél a gyökér arzén visszatartó képessége jelentősen csökkeni kezd. Az arzén transzlokációja a növény talajfelszín feletti szervei felé oly mértékben fokozódik, hogy a $270 \mathrm{mg} \mathrm{kg}{ }^{-1}$-os kezelés esetén elér egy úgynevezett kritikus arzénkoncentrációt, melynek következtében a gyökér és a szár arzén-koncentrációja már megközelítőleg azonos. Emellett drasztikus növekedés következik be a levél, hüvely, valamint borsószem arzén-koncentrációjában is.

Összességében kijelenthetö, hogy valamennyi arzénkezelés esetén az egyes növényi szervek arzén-koncentrációja az alábbiaknak megfelelöen alakult: gyökér $>$ szár > levél > hüvely > szem.

A kísérlet során kapott eredményekkel összhangban számos tanulmány arról számolt be, hogy az arzénkezelés koncentrációjának növekedésével nött az egyes növényi részek arzéntartalma (MELO et al., 2009; KUMAR et al., 2015), valamint, hogy az arzén föként a gyökérben akkumulálódott és csak kisebb mértékben volt jelen az egyéb növényi szervekben (WELLS \& GILMOR, 1997; SMITH et al., 2010). 


\section{Az arzénkezelés hatása a zöldborsó foszfor-akkumulációjára}

Az egyes növényi szervek arzéntartalma mellett vizsgáltuk az egyéb elemek felvételére gyakorolt hatását is. E szempontból kiemelkedő figyelmet fordítottunk mind a generatív mind a vegetatív szervek P-koncentrációjának meghatározására, hiszen a szakirodalmi adatok alapján a növényi felvétel során az arzenátok és foszfátok egymás antagonistái (KABATA-PENDIAS, 2010). A P-tartalom meghatározására irányuló mérések során kapott eredményeket a 3. táblázat prezentálja.

\section{3. táblázat}

As-kezelés $\left(0,3,10,30,90,270 \mathrm{mg} \mathrm{kg}^{-1}\right)$ hatása a zöldborsó egyes szerveinek P-tartalmára $\left(\mathrm{mg} \mathrm{kg}^{-1}\right)(\mathrm{n}=12)$

\begin{tabular}{|c|l|l|l|l|l|}
\hline \begin{tabular}{c} 
As- \\
\multirow{2}{*}{$\begin{array}{c}\text { kezelés } \\
\left(\mathbf{m g ~ k g}^{-1}\right)\end{array}$} \\
$(\mathbf{1})$
\end{tabular} & \multicolumn{5}{|c|}{ P-koncentráció $\left(\mathbf{m g ~ k g}^{-1}\right)(\mathbf{2})$} \\
\cline { 2 - 6 } & Gyökér (3) & Szár (4) & Levél (5) & Hüvely (6) & Szem (7) \\
\hline $\mathbf{0}$ & $2236 \pm 11^{\mathrm{a}}$ & $817 \pm 13^{\mathrm{a}}$ & $1303 \pm 16^{\mathrm{a}}$ & $964 \pm 61^{\mathrm{a}}$ & $4631 \pm 236^{\mathrm{a}}$ \\
\hline $\mathbf{3}$ & $2134 \pm 97^{\mathrm{a}}$ & $638 \pm 6^{\mathrm{a}}$ & $1119 \pm 5^{\mathrm{a}}$ & $1081 \pm 122^{\mathrm{a}}$ & $4615 \pm 162^{\mathrm{a}}$ \\
\hline $\mathbf{1 0}$ & $2179 \pm 159^{\mathrm{a}}$ & $644 \pm 14^{\mathrm{a}}$ & $1048 \pm 9^{\mathrm{a}}$ & $918 \pm 42^{\mathrm{a}}$ & $4670 \pm 140^{\mathrm{a}}$ \\
\hline $\mathbf{3 0}$ & $2310 \pm 136^{\mathrm{a}}$ & $750 \pm 9^{\mathrm{a}}$ & $1133 \pm 4^{\mathrm{a}}$ & $1137 \pm 14^{\mathrm{a}}$ & $4526 \pm 78^{\mathrm{a}}$ \\
\hline $\mathbf{9 0}$ & $3989 \pm 469^{\mathrm{b}}$ & $731 \pm 12^{\mathrm{a}}$ & $1053 \pm 7^{\mathrm{a}}$ & $1040 \pm 69^{\mathrm{a}}$ & $4402 \pm 113^{\mathrm{a}}$ \\
\hline $\mathbf{2 7 0}$ & $7097 \pm 420^{\mathrm{c}}$ & $7272 \pm 962^{\mathrm{b}}$ & $2636 \pm 107^{\mathrm{b}}$ & $5524 \pm 45^{\mathrm{b}}$ & $6911 \pm 132^{\mathrm{b}}$ \\
\hline
\end{tabular}

Statisztikai értelemben a generatív részek, illetve a levél és szár esetén a $0,3,10$, 30 és $90 \mathrm{mg} \mathrm{kg}^{-1}$-os arzénkezelés foszforfelvételre gyakorolt hatása nem különböztethető meg, ugyanakkor a $270 \mathrm{mg} \mathrm{kg}^{-1}$-os kezelés szignifikánsan növelte az említett részek P-tartalmát.

A gyökér tekintetében szignifikáns növekedést a $90 \mathrm{mg} \mathrm{kg}^{-1}$-os és a $270 \mathrm{mg} \mathrm{kg}^{-1}$ os kezelés eredményezett. A kontrollhoz viszonyítva a $90 \mathrm{mg} \mathrm{kg}^{-1}$-os kezelés 1,8 szorosára, a $270 \mathrm{mg} \mathrm{kg}{ }^{-1}$-os pedig 3,2-szeresére növelte a gyökér P-tartalmát. Fontos kiemelnünk azonban, hogy a kisebb koncentrációjú kezelések (3, 10 és 30 $\mathrm{mg} \mathrm{kg}^{-1}$ ) esetén a gyökér P-koncentrációját illetően szignifikáns eltérés nem volt tapasztalható. A legmagasabb arzénkezelés $\left(270 \mathrm{mg} \mathrm{kg}^{-1}\right)$ miatt erősen lecsökkent biomasszában egyes elemek hajlamosak töményedni, dúsulni. A P-tartalomban bekövetkező növekedés valószínúleg ennek a „töményedési effektusnak” köszönhetö.

CARBONELL-BARRACHINA és munkatársai (1997) hidropónikus körülmények között végzett kísérletük során szintén azt tapasztalták, hogy a tápközeg növekvő arzén-koncentrációjának hatására nőtt a borsó hajtásának P-tartalma. Ugyanakkor PAIVÖKE ÉS SIMOLA (2001) munkájuk során arra a megállapításra jutottak, hogy a tápközeg arzéntartalma csökkentette a borsó hajtásának P-tartalmát. 
A szem, hüvely, levél és szár esetén a $270 \mathrm{mg} \mathrm{kg}^{-1}$-os, a gyökér esetén pedig a 90 és $270 \mathrm{mg} \mathrm{kg}^{-1}$-os kezelés hatására az arzéntartalom a kisebb koncentrációjú $(0,3$, 10 és $30 \mathrm{mg} \mathrm{kg}^{-1}$ ) kezelésekhez viszonyítva egy nagyságrenddel nőtt, vagyis az egyes növényi szervek arzéntartalmában bekövetkező nagyságrendnyi növekedés és a foszfortartalom szignifikáns növekedése ugyanazon növényi rész esetén azonos kezelési szintnél következett be.

A különbözö növényi részekben akkumulálódott arzén mennyiségét, illetve ugyanazon rész foszfor-koncentrációjának arányát nézve azonban megállapíthatjuk, hogy a P/As valamennyi szerv esetén a kezelések hatására jelentősen csökkent. A levél tekintetében az arzénkezelések koncentrációjának növekedésével szignifikánsan csökkent az említett két elem aránya.

A növekvő koncentrációjú arzénkezelések hatására a P-As arány tekintetében a legnagyobb mértékủ csökkenés a levél esetén volt megfigyelhető, melynél a két elem arányának tekintetében a kontroll növény esetén tapasztalt érték 83,9-szer nagyobb volt, mint a $270 \mathrm{mg} \mathrm{kg}^{-1}$-os kezelés esetén. A levél mellett a kezelések hatására valamennyi növényi szerv esetén jelentősen csökkent a két elem aránya, a csökkenés mértékének tekintetében az alábbi sorrend állítható fel: levél > szár > hüvely > szem > gyökér. E sorrend alapján megállapítható, hogy a nagyobb mértékü csökkenés elsősorban az élénk anyagcserével rendelkező növényi szövetek esetén volt megfigyelhető, mely részek foszforigénye alapvetően nagyobb, mint más növényi szöveteknél.

A növekvő koncentrációjú arzénkezelések hatására a különböző növényi szervek P-As arányában bekövetkező változások tekintetében legérzékenyebb növényi szervnek a levél bizonyult, amelyböl adódóan a levél P-As aránya az arzénmérgezés fontos indikátora lehet. A levél analízisének segítségével az arzénmérgezés már azelőtt megállapítható mielőtt annak látható tünetei is megjelennének a növényen.

\section{Összefoglalás}

$\mathrm{Az}$ arzénnal szennyezett termőterület a világ valamennyi részére kiterjedő globális problémát jelent. Az arzén a növények számára nem esszenciális mikroelem, mely a szennyezett talajon történő növénytermesztés által a növények számára felvehetővé válik. Az arzén felvételének következtében olyan növényfiziológia folyamatok sérülhetnek, melyek súlyos anomáliák kialakulásához vezetnek.

Kutatómunkánk célja növekvő koncentrációjú $\left(0,3,10,30,90\right.$ és $\left.270 \mathrm{mg} \mathrm{kg}^{-1}\right)$ arzénkezelésben részesített talajon termesztett zöldborsó szárazanyagproduktumában bekövetkező változások nyomon követése mellett, az egyes növényi szervek (gyökér, szár, levél, hüvely, szem) arzén-akkumulációs képességének megállapítsa volt. Vizsgáltuk továbbá a talaj arzén-terhelésének hatását a kísérleti növény egyes szerveinek P-tartalmára vonatkozóan is. Munkánk tárgyát képezte továbbá a növekvő koncentrációban arzénnal kezelt talaj „összes”, illetve „oldható” arzéntartalmának megállapítása. 
Arra a következtetésre jutottunk, hogy a talaj növekvő koncentrációjú arzénterhelésének hatására valamennyi növényi szerv arzéntartalma nőtt. Az egyes növényi szervek arzén-akkumulációs képességének sorrendje a következö: gyökér > szár > levél > hüvely > szem. Habár valamennyi kezelésnél az arzén döntően a gyökérben akkumulálódott, a $270 \mathrm{mg} \mathrm{kg}^{-1}$-os kezelés esetén a gyökér már nem volt képes az arzén visszatartására, így a transzlokációja jelentősen fokozódott a talajfelszín feletti szervek irányába is.

A gyökérben akkumulálódott jelentős mennyiségü arzén a gyökér szárazanyagproduktumára nézve gátló hatást fejtett ki. A hüvely és szem esetén a legnagyobb $\left(270 \mathrm{mg} \mathrm{kg}^{-1}\right)$, míg a szár és levél esetén a legnagyobb kezelés mellett a $90 \mathrm{mg} \mathrm{kg}^{-1}$ os kezelés is szignifikánsan csökkentette az említett szervek szárazanyag-tartalmát. Ugyanakkor a $10 \mathrm{mg} \mathrm{kg}^{-1}$-os kezelés fokozta a levél és szár, míg a 3 és $10 \mathrm{mg} \mathrm{kg}^{-1}$ os kezelés növelte a generatív részek szárazanyag-tartalmát.

Az egyes szervek foszfortartalmának meghatározására irányuló vizsgálataink eredményei alapján megállapítható, hogy a szem, hüvely, levél, valamint szár esetén a $270 \mathrm{mg} \mathrm{kg}^{-1}$-os, míg a gyökérnél már a $90 \mathrm{mg} \mathrm{kg}^{-1}$-os kezelés hatására is nőtt, a kisebb koncentrációjú kezelések hatására azonban szignifikánsan nem változott az említett növényi szervek P-tartalma. A P-As arány tekintetében a kezelések hatására azonban drasztikus csökkenés volt megfigyelhető valamennyi növényi szerv esetén.

A talajvizsgálati eredmények alapján azt a konklúziót vontuk le, hogy a talaj „összes” arzéntartalmának - a különbözö adszorpciós folyamatoknak, illetve a talaj puffer kapacitásának köszönhetően - csak 38,6-56,9\% van a növények számára is hozzáférhető formában jelen.

Kulcsszavak: arzén, borsó, szárazanyag-tartalom, foszfor, talaj 


\section{IRODALOM}

AhMed, S. F. R., KILlHAm, K., AleXANDER, I., 2006. Influences of arbuscular fungus Glomus mosseae on growth and nutrition of lentil irrigated with arsenic contaminated water. Plant and Soil. 258. 33-41.

Antal, J., BuZÁs, I., Debreczeni, B., Fekete, A., NAgy, M., Sipos, S., SVÁb, J., 1979. A mütrágyázás irányelvei és üzemi számítási módszer. I. rész. N, P, K mütrágyázási irányelvek. MÉM Növényvédelmi és Agrokémiai Központ. Mezőgazdasági Kiadó, Budapest.

Carbonell-Barrachina, A. A., Burló, F., Burgos-Hernández, A., LóPez, E., MATAIX J., 1997. The influence of arsenite concentration on arsenic accumulation in tomato and bean plants. Scientia Horticulturae. 71. 167-176.

Carbonell-Barrachina, A. A., Aarabi, M. A., Delaune, R. D., Gambrell, R. P., PATRICK JR., W. H., 1998a. Bioavailability and uptake of arsenic by wetland vegetation: effects on plant growth and nutrition. Journal of Environmental Science and Health. 33. 45-66.

Carbonell-Barrachina, A. A., Burló, F., LóPez, E., MataiX, J., 1998b. Tomato plant as affected by arsenite concentration. Journal of Plant Nutrition. 21. 235-244.

Castillo-Michel, H., Parsons, J.G., Peralta-Videa, J. R., MartinezMartineZ, A., DoKKEn, K. M., GardeA-TORRESDEY, J. L., 2007. Use of X-ray absorption spectroscopy and biochemical techniques to characterize arsenic uptake and reduction in pea (Pisum sativum) plants. Plant Physiology and Biochemistry. 45. 457-463

Chilvers, D. C., Peterson P. J., 1987. Global Cycling of Arsenic. [In: Hutchinson T. C., Meema K. M. (eds.). Lead, Mercury, Cadmium and Arsenic in the Environment.]. Scope, Chichester.

ChrisPeels, M. J., Crawford, N. M., SChroeder, J. I., 1999. Proteins for transport of water and mineral nutrients across the membranes of plant cells. The Plant Cell. 11. 661-676.

CULLEN, W. R., REIMER, K. J., 1989. Arsenic speciation in the environment. Chemical Reviews. 89. 713-764.

CZIPA, N., ANDRÁSI, D., KovÁCS, B., 2015. Determination of essential and toxic elements in Hungarian honeys. Food Chemistry. 175. 536-542.

GonZaGA, M. I. S., SANTOS, J. A. G., MA, L. Q., 2006. Arsenic phytoextraction and hyperaccumulation by fern species. Scientia Agricola. 63. 90-101.

Gulz, P. A., GuPTA, S. K., 2000. Arsenaufnahme von Kulturpflanzen. Agrarforschung Schweiz. 7. 360-365.

Jacobs, L. W., KeENEY, D. R., Walsh, L. M., 1970. Arsenic residue toxicity to vegetable crops grown on plainfield sand. Agronomy Journal. 62. 588-591.

Kabata-Pendias, A., 2010. Trace Elements in Soils and Plants ( $4^{\text {th }}$ edition). CRC Press. Boca Raton, FL.

KÁDÁR, I., 1991a. A talajok és növények nehézfémtartalmának vizsgálata. KTM, MTA TAKI, Budapest. 
KÁDÁR, I., 1991b. Környezet- és természetvédelmi kutatások. A talajok és növények nehézfémtartalmának vizsgálata. KTM, MTA TAKI, Budapest.

KÁDÁR, I., 1995. A talaj-növény-állat-ember tápláléklánc szennyeződése kémiai elemekkel Magyarországon. KTM, MTA TAKI, Budapest.

Koch, I., Wang, L., Ollson, C. A., Cullen, W. R., Reimer, K. J., 2000. The predominance of inorganic arsenic species in plants from Yellowknife, Northwest territories, Canada. Environmental Science and Technology. 34. 2226.

KovÁcs, B., GYŐRI, Z., PROKISCH, J., LOCH, J., DÁNIEL, P., 1996. A study of plant sample preparation and inductively coupled plasma emission spectrometry parameters. Communications in Soil Science and Plant Analysis. 27. 1177-1198.

KovÁcs, B., Prokisch, J., GYÖRI, Z., BAlla Kovács, A., PALENCSÁr, A. J., 2000. Analytical methods and quality assurance. Communications in Soil Science and Plant Analysis. 31. 11-14,

Kumar, D., Singh, V. P., TriPathi, D. K., Prasad, S. M., Chauhan, D. K., 2015. Effect of arsenic on growth, arsenic uptake, distribution of nutrient elements and thiols in seedlings of Wrightia arborea (Dennst.) Mabb. International Journal of Phytoremediation. 23. 128-134.

LAKANEN, E., ERVIÖ, R., 1971. A comparison of eight extractants for determination of plant available micronutrients in soil. Acta Agronomica Fennica. 123. 23-232.

LiaO, X. Y., Chen, T. B., LeI, M., HuAnG, Z. C., XiAO, X. Y., AN, Z. Z., 2004. Root distributions and elemental accumulations of Chinese brake (Pteris vittata L.) from As-contaminated soils. Plant and Soil. 261. 109-116.

Liu, C., MuchHal, U. S., Uthappa, M., Kononowicz, A. K., Raghothama, K. G., 1998. Tomato phosphate transporter genes are differentially regulated in plant tissues by phosphorus. Plant Physiology. 116. 91-99.

LiU, Q., Hu, C., TAN, Q., Sun, X., Su, J., LianG, Y., 2008. Effects of As on As uptake, speciation, and nutrient uptake by winter wheat (Triticum aestivum L.) under hydroponic conditions. Journal of Environmental Sciences. 20. 326-331.

Mallick, S., SinAm, G., SinHA, S., 2011. Study on arsenate tolerant and sensitive cultivars of Zea mays L.: Differential detoxification mechanism and effect on nutrients status. Ecotoxicology and Environmental Safety. 74. 1316-1324.

MANDAL, B., K., SuZUKI, K. T., 2002. Arsenic round the world: A review. Talanta. 58. 201-235.

Mattusch, J., WennRICh, R., SChmidt, A. C., Reisser W., 2000. Determination of arsenic species in water, soils and plants. Fresenius Journal of Analytical Chemistry. 366. 200-203.

Melo, E. E. C., Costa, E. T. S., Guilherme, L. R. G., Faquin, V., Nascimento, C. W. A., 2009. Accumulation of arsenic and nutrients by castor bean plants grown on an As-enriched nutrient solution. Journal of Hazardous Materials. 168. 479-483. 
MokgalaKa-Matlala, N. S., Flores-Tavizon, E., Castillo-Michel, H., Peralta-VideA, J. R., GardeA-TorResdey, J. L., 2008. Toxicity of arsenic(III) and (V) on plant growth, element uptake, and total amylolytic activity of mesquite (Prosopis juliflora x P. velutina). International Journal of Phytoremediation. 10. 47-60.

Moreno-Jiménez, E., Esteban, E., PeÑalosa, J. M., 2012. The Fate of Arsenic in Soil-Plant Systems. [In: Whitacre D. M. (ed.). Reviews of Environmental Contamination and Toxicology, Reviews of Environmental Contamination and Toxicology.]. Springer Science+Business Media LLC. New York.

MukherJeE, A. B., Bhattacharya, P., 2001. Arsenic in the groundwater in the Bengal Delta Plain: slow poisoning in Bangladesh. Environmental Research. 9. 189-220.

PaivöKe, A. E. A., Simola, L. K., 2001. Arsenate toxicity to Pisum sativum: mineral nutrients, chlorophyll content, and phytase activity. Ecotoxicology and Environmental Safety. 49. 111-121.

PetHÖ, M., 1993. Mezőgazdasági növények élettana. Akadémiai Kiadó, Budapest.

Pigna, M., Cozzolino, V., Giandonato Caporale, A., Mora, M. L., Di Meo, V., JARA, A.A., Violante, A., 2010. Effects of phosphorus fertilization on arsenic uptake by wheat grown in polluted soils. Journal of Soil Science and Plant Nutrient. 10. 428-442.

Quaghebeur, M., ReNGel, Z., 2003. The distribution of arsenate and arsenite in shoots and roots of Holcus lanatus is influenced by arsenic tolerance and arsenate and phosphate supply. Plant Physiology. 132. 1600-1609.

RaAb, A., Ferreira, K., Meharg, A. A., Feldmann, J., 2007. Can arsenicphytochelatin complex formation be used as an indicator for toxicity in Helianthus annuus? Journal of Experimental Botany. 58. 1333-1338.

Rowland, H. A. L., Omoregie, E. O., Millot, R., Jimenez, C., Mertens, J., BACIU, C., HUG, S. J., BERG, M., 2011. Geochemistry and arsenic behaviour in groundwater resources of the Pannonian Basin (Hungary and Romania). Applied Geochemistry. 26. 1-17.

SCHMÖGER, M. E. V., OVEN, M., GRILL, E., 2000. Detoxification of arsenic by phytochelatins in plants. Plant Physiology. 122. 793-801.

Shaibur, M. R., Kitajima, N., Sugewara, R., Kondo, T., Alam, S., Imamul HuQ, S .M., KAWAI, S., 2008. Critical toxicity of arsenic and elemental composition of arsenic-induced chlorosis in hydroponic sorghum. Water Air Soil Pollution. 191. 279-292.

SMEDley, P. L., KINNIBURGH, D. G., 2002. A review of the source, behaviour and distribution of arsenic in natural waters. Applied Geochemistry. 17. 517-568.

SMith, S. E., Christophersen, H. M., Pope, S., SMith, F. A., 2010. Arsenic uptake and toxicity in plants: integrating mycorrhizal influences. Plant and Soil. 327. 121. 
Srivastava, S., Srivastava, A. K., Suprasanna, P., D'SouZa, S. F., 2009. Comparitive biochemical and transcriptional profiling of two contrasting varities of Brassica juncea $\mathrm{L}$. in response to arsenic exposure reveals mechanisms of stress perception and tolerance. Journal of Experimental Botany. 181. 1-13.

SzEGEDI, L., BÉlteKI, I., FodORNÉ FeHÉR, E., 2013. A talaj és növények arzén tartalmának összefüggés vizsgálata nehézfém terheléses tartamkísérletben. Acta Carolicus Roberticus. 3. 135-144.

TU, C., MA, L. Q., 2005. Effect of arsenic concentration and distribution of nutrients in the fronds of the arsenic hyperaccumulator Pteris vittata L. Environmental Pollution. 135. 333-340.

UllRich-EberiUs, C. I., SANZ, A., NOVACKY, A. J., 1989. Evaluation of arsenateand vanadate-associated changes of electrical membrane potential and phosphate transport in Lemna gibba G1. Journal of Experimental Botany. 40. 119-128.

Wells, B. R., GILMOR, J. T., 1977. Sterility in rice cultivars as influenced by MSMA rate and water management. Agronomy Journal. 69. 451-454.

Williams, P. N., Price, A. R., RaAb, A., Hossain, S. A., Feldmann, J., Meharg, A. A., 2005. Variation in arsenic speciation and concentration in paddy rice related to dietary exposure. Environmental Science and Technology. 39. 55315540.

Woolson, E. A., Axley, J. H., Kearney, P. C., 1971. Correlation between available soil arsenic, estimated by six methods, and response of corn (Zea mays L.). Soil Science Society of America Journal. 35. 101-105.

XU, J., THORNTON I., 1985. Arsenic in garden soils and vegetable crops in Cornwall, England: implications for human health. Environmental Geochemistry and Health. 7. 131-133. 


\title{
Effect of arsenic treatments on the arsenic and phosphorus concentration and dry matter accumulation of green pea
}

\author{
${ }^{1}$ S. VÁRALLYAY, ${ }^{2}$ A. BALLÁNÉ KOVÁCS, ${ }^{1}$ Á. SOÓS and \\ ${ }^{1}$ B. KOVÁCS \\ ${ }^{1}$ Institute of Food Science, ${ }^{2}$ Department of Agricultural Chemistry and Soil Science, \\ Faculty of Agricultural and Food Sciences and Environmental Management, \\ University of Debrecen, Debrecen
}

\section{Summary}

The contamination of soil by arsenic is a global problem affecting many parts of the world. Arsenic occurs in soil mainly as inorganic arsenic species, namely arsenate $[\mathrm{As}(\mathrm{V})]$ and arsenite $[\mathrm{As}(\mathrm{III})]$. These two forms of arsenic are toxic for plants. The uptake of arsenic from soils contaminated with arsenic leads to physiological changes. Arsenic is able to influence the uptake of other elements by competing with macro- and microelements for transporters. Several authors have investigated the effect of arsenate on the uptake of phosphorus by plants, because arsenate and phosphate are chemically very similar, and they share the same transport pathway in plants. However, the findings in this research area are contradictory.

The objective of the present study was to investigate the effect of arsenate on the dry weight of green pea. A further aim was to investigate the effect of arsenate treatments on phosphorus uptake. The total and plant-available As content of the soil was also determined. The experiment was carried out in a greenhouse on calcareous chernozem soil. The element content of the samples was determined by ICP-MS (inductively coupled plasma mass spectrometry) and ICP-OES (inductively coupled plasma optical emission spectrometry).

Arsenate had a clear impact on the dry weight, decreasing that of the roots. Its effect was less clear-cut in the case of the leaves and stems, as the $10 \mathrm{mg} \mathrm{kg}^{-1} \mathrm{As}$ treatment increased the dry weight of the samples, while the 90 and $270 \mathrm{mg} \mathrm{kg}^{-1}$ treatments decreased it. The generative organs also exhibited an increase in dry mass up to $10 \mathrm{mg} \mathrm{kg}^{-1} \mathrm{As}$, after which a decreasing tendency was observed.

Element analysis showed that arsenic was accumulated mainly in the root system, and only smaller amounts were translocated to the aboveground parts of the plants. However, the translocation of arsenic from the roots towards other plant organs increased if the soil was treated with at least $90 \mathrm{mg} \mathrm{kg}^{-1}$ As. The As content of all green pea organs tended to rise as the As rate increased. The arsenic concentration of individual plant parts decreased in the order: root $>$ stem $>$ leaf $>$ pod $>$ pea. 
The results of the greenhouse experiment indicated a decline in the P-As ratio in various plant organs, especially in the leaves, suggesting that the leaf As-P ratio could be a useful indicator of arsenic toxicity.

It was found that only $38.2-56.9 \%$ of the total arsenic content in the soil was available to plants.

Table 1. Soil properties in the greenhouse experiment. (1) Depth. (2) Plasticity index according to Arany. (3) Total water-soluble salt content. (4) Humus. (5) ALsoluble $\mathrm{P}_{2} \mathrm{O}_{5}$. (6) AL-soluble $\mathrm{K}_{2} \mathrm{O}$. (7) $\mathrm{KCl}$-soluble $\mathrm{NO}_{3}-\mathrm{N}+\mathrm{NO}_{2}-\mathrm{N}$. (8) AL-soluble Na. (9) KCl-soluble Mg. (10) KCl-soluble $\mathrm{SO}_{4}{ }^{2-}$-S. (11) KCl-EDTA-soluble $\mathrm{Cu}$. (12) KCl-EDTA-soluble Zn. (13) KCl-EDTA-soluble Mn.

Table 2. Total and Lakanen-Erviö-soluble As content $\left(\mathrm{mg} \mathrm{kg}^{-1}\right)$ in the different arsenic treatments $\left(0,3,10,30,90,270 \mathrm{mg} \mathrm{kg}^{-1}\right)(\mathrm{n}=3)$. (1) As treatments $\left(\mathrm{mg} \mathrm{kg}^{-}\right.$ $\left.{ }^{1}\right)$. (2) Total As content $\left(\mathrm{mg} \mathrm{kg}^{-1}\right)$. (3) Lakanen-Erviö-soluble As content $\left(\mathrm{mg} \mathrm{kg}^{-1}\right)$.

Table 3. Effect of various As treatment $\left(0,3,10,30,90,270 \mathrm{mg} \mathrm{kg}^{-1}\right)$ on the $\mathrm{P}$ content $\left(\mathrm{mg} \mathrm{kg}^{-1}\right)$ of different green pea organs $(\mathrm{n}=12)$. (1) As treatment $\left(\mathrm{mg} \mathrm{kg}^{-1}\right)$. (2) P content ( $\mathrm{mg} \mathrm{kg}^{-1}$ ). (3) Root. (4) Stem. (5) Leaf. (6) Pod. (7) Seed.

Figure 1. Effect of different As treatments $\left(0,3,10,30,90,270 \mathrm{mg} \mathrm{kg}^{-1}\right)$ on the dry weight of green pea pods $\left(\mathrm{g} \mathrm{plant}^{-1}\right)(\mathrm{n}=12)$. (1) Dry weight of green pea pods $\left(\mathrm{g} \mathrm{plant}^{-1}\right)$. (2) As treatments $\left(\mathrm{mg} \mathrm{kg}^{-1}\right)$.

Figure 2. Effect of different As treatments (0, 3, 10, 30, 90, $\left.270 \mathrm{mg} \mathrm{kg}^{-1}\right)$ on the dry weight of pea seeds $\left(g\right.$ plant $\left.^{-1}\right)(\mathrm{n}=12)$. (1) Dry weight of pea seeds $\left(\mathrm{g}\right.$ plant $\left.^{-1}\right)$. (2) As treatments $\left(\mathrm{mg} \mathrm{kg}^{-1}\right)$.

Figure 3. Effect of different As treatments (0, 3, 10, 30, 90, $\left.270 \mathrm{mg} \mathrm{kg}^{-1}\right)$ on the dry weight of green pea roots $\left(g_{\text {plant }}^{-1}\right)(n=12)$. (1) Dry weight of green pea roots $\left(\mathrm{g} \mathrm{plant}^{-1}\right)$. (2) As treatments $\left(\mathrm{mg} \mathrm{kg}^{-1}\right)$.

Figure 4. Effect of different As treatments $\left(0,3,10,30,90,270 \mathrm{mg} \mathrm{kg}^{-1}\right)$ on the dry weight of green pea leaves and stems $\left(g\right.$ plant $\left.^{-1}\right)(n=12)$. (1) Leaf. (2) Dry weight of green pea leaves $\left(\mathrm{g} \mathrm{plant}^{-1}\right)$. (3) As treatments $\left(\mathrm{mg} \mathrm{kg}^{-1}\right)$. (4) Stem. (5) Dry weight of green pea stems $\left(\mathrm{g} \mathrm{plant}^{-1}\right)$.

Figure 5. Effect of different As treatments $\left(0,3,10,30,90,270 \mathrm{mg} \mathrm{kg}^{-1)}\right.$ on the As content $\left(\mathrm{mg} \mathrm{kg}^{-1}\right)$ in different green pea organs $(\mathrm{n}=12)$. (1) Generative parts of green pea. (2) As content in pea pods $\left(\mathrm{mg} \mathrm{kg}^{-1}\right)$. (3) As treatments $\left(\mathrm{mg} \mathrm{kg}^{-1}\right)$. (4) As content in pea seeds $\left(\mathrm{mg} \mathrm{kg}^{-1}\right)$. (5) Pea pods. (6) Seeds. (7) Vegetative parts of green pea. (8) As concentration ( $\mathrm{mg} \mathrm{kg}^{-1}$ ). (9) As treatments $\left(\mathrm{mg} \mathrm{kg}^{-1}\right)$. (10) Leaf. (11) Stem. (12) Root.

Keywords: arsenic, pea, dry matter content, phosphorus, soil 